\title{
DESCRIPTION OF CESTODES INFECTING DOMESTICATED PIGEON (COLUMBA LIVIA DOMESTICA) IN EGYPT WITH SPECIAL REFERENCE TO THE MOLECULAR CHARACTERIZATION OF RAILLIETINA SPP.
} By

MARWA SAFI-ELDIN, HODA A.TAHA and AMEEN A. ASHOUR

Department of Zoology, Faculty of Science, Ain Shams University, 11566, Egypt

( ${ }^{*}$ Correspondence: marwa.safieldin.ms@gmail.com)

\begin{abstract}
This study investigated the prevalence and the specific identity of cestode parasites isolated from the digestive tract of domestic pigeon (Columba livia domestica) in Cairo, Egypt. Out of 246 pigeons, $61(24.79 \%)$ were infected by one or more species. Eight helminthes species were recorded; three nematodes; Ascaridia galli, A. columbae and Heterakis gallinarum and five cestodes; Raillietina echinobothrida, R. tetragona, R. sp., Cotugnia digonopora and Choanotaenia infundibulum. No trematodes were recorded. The morphological observations, using light microscope, were employed for precise identification of cestodes with particular attention to molecular identity of Raillietina spp. using two molecular techniques: RAPD-PCR and SSCP-PCR.
\end{abstract}

Keywords: Prevalence, Pigeon, Cestodes, SSCP-PCR, RAPD-PCR.

\section{Introduction}

In Egypt, poultry farming has become one of the most intensive forms of animal husbandry activities (Satish and Priti, 2013). The commonly kept poultry are chickens (Gallus spp.), pigeons (Columba spp.), ducks (Anas spp.), geese (Anser spp.) and turkeys (Meleagris spp.). Poultry products are considered as one of the most important protein sources (meat and eggs) for man worldwide (FAO, 1997; Branckaert et al, 2000). Most of the products are from chickens, but turkeys, pigeons, geese and ducks are important sources as well. Birds in rural production systems are at a constant risk of infections and diseases, especially endoparasites (Catelli et al, 1999; Dessie and Ogle, 2001; Eshetu et al, 2001).

Helminthes of poultry can reduce weight gain, feed efficiency, and production losses in breeders. It can also lead to significant growth depression and mortality in birds (Ikeme, 1971 and Ruff, 1999). In general, parasitism negatively affects productivity of the local scavenging birds since they either compete for feed or cause distress to the birds (Mungube et al, 2008).

Domestic pigeon (Columba livia domestica) is a member of order Columbiformes and considered as cosmopolitan of acclimate conditions world-wide (Sari et al, 2008). The endo-parasitism is one of the most important forms of disease affecting poultry (Dranzoa et al, 1999). The commonest cestode parasites are Raillietina, choanotaenia, Hymenolepis and Davainea species. Raillietina group represents over 200 species (Jadhav and Gore, 2004), with infected ones may cause high rates of morbidity and mortality.

However, the morphological criteria of Raillietina spp. in particular, showed a wide range of variations within and between species, difficult to identify by morphology Caira et al, 2014). Many molecular techni-ques (RAPD-PCR, RFLP, SSCP \& LSSP) clarified knowledge of genus Raillietina. Some DNA regions (internal transcribed spacer (ITS) gene, Cytochrome C oxidase (CO1) and nicotinamide adenine dinucleo-tide dehydrogenase subunit 1 (ND1) gene identified helminthes between species (Al Quraishy et al, 2019). Molecular techniques with morphological analyses proved useful for helminthic identification (Eom et al, 2002; Lavikainen et al, 2008).

The present study aimed to explore the intestinal helminth parasite prevalence with particular attention to cestodes. Molecular characterization of Raillietina spp. was dete- 
rmined using two molecular DNA analysis; RAPD-PCR and SSCP-PCR.

\section{Materials and Methods}

The study was performed on 246 domestic pigeons (Columba livia domestica) randomly collected from 2015 to 2017 . Their intestines were dissected out for examination. They (small intestine and caecum) were opened longitudinally, rinsed with physiological saline ( $0.85 \%$ normal saline) and mucosa was scraped to collect the worms embedded in the mucosal layer. Worms were carefully washed in saline in Petri dishes, examined under a dissecting microscope and prepared for light microscopic examination and molecular investigations.

Light microscopy: Worms were gently relaxed between two slides, fixed in $10 \%$ formalin, stained with acetocarmine dye for $30 \mathrm{~min}$., differentiated in acidified $70 \%$ ethanol followed by ascending series of ethanol and then cleared in clove oil, examined and photographed using light photomicroscope. Parasitic species prevalence was determined as the proportion of the host population infected with a certain parasite seasonally (Thrusfield, 1995).

DNA extraction (CTAB method): Three morphologically Raillietina species were $(R$. echinobothrida, $R$. tetragona and $R$. sp.) recovered from pigeon. The tissue samples were homogenized in $250 \mu \mathrm{l}$ of lysis buffer $(100 \mathrm{mM}$ Tris- $\mathrm{HCl}, \quad 1.4 \mathrm{M} \mathrm{NaCl}, 20 \mathrm{mM}$ EDTA and $10 \%$ SDS) then $250 \mu 1$ of CTAB buffer $(200 \mathrm{mM}$ Tris- $\mathrm{HCl}, 1.4 \mathrm{M} \mathrm{NaCl}$,
$20 \mathrm{mM}$ EDTA, CTAB powder and $2 \%$ Bmercaptoethanol) with $25 \mu 1$ of $20 \mathrm{mg} / \mathrm{ml}$ proteinase $\mathrm{K}$ were added. The homogenates were incubated at $65^{\circ} \mathrm{C}$ in water bath for 2-3 hours. DNA purification was performed by chloroform-isoamyl alcohol (24:1) and precipitated by isopropanol. Pure DNA pellets were dissolved in $100 \mu \mathrm{l}$ of sterile $\mathrm{dH}_{2} \mathrm{O}$ and kept in $-20^{\circ} \mathrm{C}$ until used.

RAPD- PCR technique: Twenty decimer oligonucleotide primers were used to determine those primers that produced reproducible RAPD patterns. Each primer was tested three times. Good and distinct patterns were produced only using 6 arbitrary primers (Tab.1). PCR amplifications were performed (Williams et al, 1990), using six selected primers (Tab. 1). The $25 \mu 1$ mixture contained about $1 \mu \mathrm{l}$ of DNA template, 1.5 unit of Taq. polymerase, $1 \mu \mathrm{l}$ of $10 \mathrm{mM}$ dNTPs, $1 \mu 1$ of 10 pmol primer, and $2.5 \mu 1$ of 10x PCR buffer. Amplifications were done in T-personal thermal cycler (Biometra, Germany), programmed for 45 cycles at $94^{\circ} \mathrm{C}$ for $1 \mathrm{~min}, 35^{\circ} \mathrm{C}$ for $1 \mathrm{~min}$ and $72^{\circ} \mathrm{C}$ for $1 \mathrm{~min}$. An initial denaturation step $\left(3 \mathrm{~min}\right.$. at $\left.94^{\circ} \mathrm{C}\right)$ and final extension holding $\left(10 \mathrm{~min} .72^{\circ} \mathrm{C}\right)$ were included in the first and last cycles, respectively. Reaction products $(10 \mu \mathrm{l})$ were resolved by $1.5 \%$ agarose gel electrophoresis in $1 \mathrm{X}$ TAE buffer $(100 \mathrm{mM}$ Tris- $\mathrm{HCl}$, glacial acetic acid and 20mM EDTA). The gel was stained with Ethidium bromide and photographed by digital camera under UV transilluminator.

Table 1: Nucleotide sequences of six arbitrary primers and their $(\mathrm{G}+\mathrm{C})$ contents

\begin{tabular}{|l|l|c|c|}
\hline \multicolumn{1}{|c|}{ Primer code } & Primer sequence $\left(\right.$ 5`3` $^{`}$ & MWT & GC\% \\
\hline P8 & 5-GAAACACCCC-3` & 2966 & 60 \\
\hline P9 & 5-TGTAGCTGGG-3` & 3099 & 60 \\
\hline P10 & 5-ACGCGCATGT-3` & 3028 & 60 \\
\hline P12 & 5-ACGCGCATGT-3` & 3028 & 60 \\
\hline P13 & 5-CACTCTCCTC-3` & 2899 & 60 \\
\hline P33 & 5-GCACTAAGAC-3` & 2987 & 50 \\
\hline
\end{tabular}

PCR for specific primers: Specific PCR technique was carried out using two pairs of specific primers to amplify the $12 \mathrm{~S}$ rRNA and Cytochrome $\mathrm{C}$ oxidase genes (Tab. 2). PCR amplifications for Cytochrome C oxidase \& 12S rRNA genes respectively using the forward and reverse primers (Dinkel et $a l, 2004)$. A- Cytochrome $C$ oxidase subunit 1 (CO1) gene: Thermocycler conditions were: $5 \mathrm{~min}$ at $95^{\circ} \mathrm{C}$ (initial denaturation), 35 cycles of $1 \mathrm{~min}$ at $95^{\circ} \mathrm{C}$, annealing for $1 \mathrm{~min}$ at $54^{\circ} \mathrm{C} \& 1 \mathrm{~min}$ at $72^{\circ} \mathrm{C}, \& 5 \mathrm{~min}$ at $72^{\circ} \mathrm{C}$ 
(final extension). B- Mitochondrial 12S rRNA gene: PCR program conditions were as follows: 1 cycle at $95^{\circ} \mathrm{C}$ for $5 \mathrm{~min}$ before the 40 cycles of PCR (Hot start PCR) and adding 1 cycle at $72^{\circ} \mathrm{C}$ for $10 \mathrm{~min}$ after 40 cycles. Then 40 cycles (denaturation for $30 \mathrm{~s}$ at $94^{\circ} \mathrm{C}$, annealing for $1 \mathrm{~min}$ at $56^{\circ} \mathrm{C}$ and elongation for $40 \mathrm{~s}$ at $72^{\circ} \mathrm{C}$ ).

Table 2: Nucleotide sequences of the two pairs of specific primers and their $(\mathrm{G}+\mathrm{C})$ contents

\begin{tabular}{|c|c|c|c|}
\hline \multicolumn{2}{|c|}{ Primer code } & Primer sequence (5`-3`) & Bases number \\
\hline \multirow{2}{*}{ CO1 } & JB3 Forward & 5-TTT TTT GGG CAT CCT GAG GTT TAT-3` & 24 \\
\cline { 2 - 4 } & JB4.5 reverse & 5-TAA AGA AAG AAC ATA ATG AAA ATG-3` & 24 \\
\hline \multirow{2}{*}{ ITS1 } & EgF Forward & 5`GTC GTA ACA AGG TTT CCG TAG G -3` & 22 \\
\cline { 2 - 4 } & EgR Reverse & 5`TAG ATG CGT TCG AAG TGT CG -3 & 20 \\
\hline
\end{tabular}

The SSCP assay was performed (Zhu and Gasser, 1998). Four $\mu$ l of PCR sample was added to $8 \mu$ l of loading dye (6X), and mixed well. After denaturation at $94^{\circ} \mathrm{C}$ for $10 \mathrm{~min}$ and subsequent snap cooling on a freeze block $\left(-20^{\circ} \mathrm{C}\right), 8 \mu 1$ of each sample were subjected to $10 \%$ polyacrylamide gel electrophoresis. After electrophoresis, gel was stained with $0.4 \%$ silver nitrate, visualized over Transilluminator plate with ordinary light, and photographed by a digital camera.

Data Analysis: All individual bands were scored as present or absent ( 1 or 0 ) for each species. Similarity coefficient (SC) was calculated (Nei and Li, 1979) as follows: $\mathrm{SC}=2$ $\mathrm{Nxy} / \mathrm{Nx}+\mathrm{Ny}$. Nxy referred to bands number shared between 2 species ( $\mathrm{x} \& \mathrm{y}$ ) and $\mathrm{Nx} \&$ $\mathrm{Ny}$ as they were amplified only by species $\mathrm{x}$ and $y$, respectively.

\section{Results}

Out of 246 examined samples, total prevalence was $19.5 \%$. In summer (June-Aug), out of 75 samples, 8 (10.6\%) were positive, in the fall season (Sept-Nov), 154 of which $40(25.9 \%)$ were positive. In the spring season (March-May), 17 examined samples were cestode-free. But, 9 out of 246 (3.65\%) samples were positive with single nematode infection. In summer (June-Aug), 2 out of 75 $(2.66 \%)$ were positive, in fall season (SeptNov), 7 out of 154 (4.54\%) were positive with single infection. None was detected in winter and spring. Mixed infections (nematodes and cestodes) were in $4(2.59 \%)$ samples in the fall season.

Collectively, five cestode species were in pigeon's intestines ( $R$. echinobothrida, $R$. tetragona, $R$. sp., Cotugnia digonopora and Choanotaenia infundibulum).

1- Raillietina tetragona (Molin, 1858): A common tapeworm in the domestic birds. Strobila is $35 \mathrm{~cm}$ with a small oval scolex (Fig. 1A) of $0.17 \mathrm{~mm}$ in diameter, Rostellum measures about $0.07 \times 0.06 \mathrm{~mm}$, with about 100 hammer-shaped hooks in a single row measured $0.01 \mathrm{~mm}$ in length. Scolex with four large, oval, and armed suckers measured $0.0 \times 0.05 \mathrm{~mm}$ in diameter. Suckers armed with 5 to 7 rows of hooks measure less than $0.01 \mathrm{~mm}$ in length. Neck long measured $0.35 \times 0.02 \mathrm{~mm}$, imamture proglottid $0.45 \times 0.2 \mathrm{~mm}$. Mature one (Fig. 1B) measured $1.3 \times 0.45 \mathrm{~mm}$, testes nearly rounded with $0.04 \mathrm{~mm}$ diameter ranged from 25 to 28 leading to an oval cirrus pouch, extending beyond ventral longitudinal excretory canal measured $0.27 \times 0.06 \mathrm{~mm}$.

Genital pores located unilateral, open anteriorly in segment to middle portion with $0.09 \mathrm{~mm}$ in diameter, ovary measured $0.2 \mathrm{~mm}$ in diameter, gravid proglottid (Fig. 1C) measured $0.9 \times 0.6 \mathrm{~mm}$, uterus with egg capsules 6 to 9 eggs in each capsule, egg diameter $0.01 \mathrm{~mm}$, excretory canal diameter $0.02 \mathrm{~mm}$.

2- Raillietina echinobothrida: (Mégnin, 1880): Body long $25 \mathrm{~cm}$, scolex spherical in shape and measures $0.27 \mathrm{~mm}$ in diameter (Fig. 2A). Rostellum disc-shaped, nearly rounded measured $0.1 \times 0.07 \mathrm{~mm}$, circularly lined with about 200 mattock-shaped hooks with an extended base and a pointed tip arranged in two distinct rows of $0.011 \mathrm{~mm}$ in length. Four rounded suckers, rather spaced from one another, each measured $0.09 \times 0.06 \mathrm{~mm}$; armed with 6 to 8 rows of 
hooklets. Neck region short, unsegmented measured $0.45 \times 0.17 \mathrm{~mm}$.

Mature segment (Fig.2B) measured $0.7 \times 0.24 \mathrm{~mm}$, with 23 to 26 testes measured $0.04 \mathrm{~mm}$ in diameter and cirrus pouch measured $0.06 \mathrm{~mm}$ in length. Genital pores unilaterally arranged at posterior to middle region of each segment and measured $0.02 \mathrm{~mm}$ in diameter. Ovary oval and measures $0.04 \mathrm{~mm}$ in diameter, Gravid one (Fig. 2C) measured $1.2 \times 1 \mathrm{~mm}$. Eggs in egg capsule ranged from 4 to 7 with diameter $0.03 \mathrm{~mm}$, excretory canal $0.02 \mathrm{~mm}$ in diameter.

3-Rallietina sp.: is a small tapeworm, with a very minute scolex (Fig. 3A), some-how square in shape and measures $0.2 \times 0.2 \mathrm{~mm}$ in length and width. Rostellum about $0.05 \mathrm{x}$ $0.08 \mathrm{~mm}$ with about 200 hooklets arranged in double rows measured $0.01 \mathrm{~mm}$ in length. Four large and oval suckers armed with 6 to 8 rows of ho-oklets measured $0.17 \times 0.07 \mathrm{~mm}$. Neck very long $1.3 \times 0.1 \mathrm{~mm}$, mature proglottid (Fig. 3B) measured $0.65 \times 0.25 \mathrm{~mm}$, testes rounded with diameter of $0.02 \mathrm{~mm}$ with number from 30 to 36 . Cirrus pouch oval elongated measured $0.16 \mathrm{~mm}$ in length, Ovary bilobed measured $0.16 \mathrm{~mm}$ in diameter.

Genital pores measure $0.06 \mathrm{~mm}$ in diameter, located unilateral and open anteriorly to the middle portion of each segments. Gravid proglottid (Fig. 3C) measured 1.6x $0.6 \mathrm{~mm}$, egg capsules with from 4 to 8 eggs in each, egg diameter $0.01 \mathrm{~mm}$, excretory canal $0.03 \mathrm{~mm}$ in diameter.

4- Cotugnia digonopora (Pasquale, 1890): Worm size varied from 7 to $12 \mathrm{~cm}$ in length. Scolex (Fig.4A) large measured $0.6 \mathrm{~mm}$ in transverse diameter, with four well developed cup-shaped, unarmed suckers. Each measures from $0.1 \times 0.15 \mathrm{~mm}$ in diameter. Scolex apically with a rostellum, $0.3 \mathrm{~mm}$ in diameter, armed with double rows of very minute hooks, measured $0.01 \mathrm{~mm}$ in length and neck measured $0.2 \mathrm{~mm}$ in width.

Mature segment (Fig. 4B) rectangular in shape with pointed posterior corners measured $2.5 \times 0.5 \mathrm{~mm}$, with double set of ge-nital organs and two genital openings (bila-teral) in middle of lateral margins of each segment with diameter of $0.05 \mathrm{~mm}$. Testes 37 to 42 in each set, at center of segment measured about $0.0 \mathrm{~mm}$ in diameter. Cirrus pouch measured $0.17 \times 0.04 \mathrm{~mm}$. Ovary bilo- bed measured $0.03 \mathrm{~mm}$ in width. Gravid proglottid $3.7 \times 1.5 \mathrm{~mm}$ (Fig. 4C). Each egg capsule with a single egg of $0.03 \mathrm{~mm}$ diame- ter, excretory canal measured $0.5 \mathrm{~mm}$ in dia-meter.

5- Choanotaenia infundibulum (Bloch, 1779): Worm measured $15-22 \mathrm{~cm}$ long $\mathrm{x}$ up to $3 \mathrm{~mm}$ wide, scolex (Fig. 5A) triangular to oval in shape, somehow pointed anteriorly and measured $0.27 \mathrm{~mm}$ in width. Rostellum measured $0.8 \times 0.6 \mathrm{~mm}$, armed with 16 slender hooks arranged in one row. Four more or less oval, unarmed suckers measured $0.18 \mathrm{x}$ $0.12 \mathrm{~mm}$, Neck narrow, short and measured $0.2 \times 0.25-0.3 \mathrm{~mm}$.

Immature proglottid measured $0.31 \times 0.23$ mm. Mature one (Fig. 5B) more or less bell shaped, broader posteriorly than anteriorly with pointed posterior corners with serrated appearance, measured $1.15 \times 0.7 \mathrm{~mm}$ in length. Testes nearly rounded with range number from 3 to 40 measured $0.04 \mathrm{~mm}$ in diameter. Cirrus pouch elongated, located in anteriorly measured $0.17 \times 0.05 \mathrm{~mm}$, opened in genital pore measured $0.07 \mathrm{~mm}$ in diameter and alternates irregularly. Ovary branched measured $0.09 \mathrm{~mm}$ in diameter with a highly lobed uterus. Gravid srgment (Fig. 5C) large, measured $3 \times 2.5 \mathrm{~mm}$. Eggs encapsulated with a single egg in each, rounded measured 0.03 to $0.04 \mathrm{~mm}$ in diameter. Excretory canal measured $0.04 \mathrm{~mm}$ in diameter.

Raillietina species molecular characters: Totally, RAPD-PCR analysis used six arbitrary primers on the genome of $R$. echinobothrida, $R$. tetragona, and $R$. sp. (2 samples of each and one sample of $R$. sp.) showed an a average amplified DNA fragments of 35 bands for $R$. echinobothrida, 33 for $R$. tetragona and 21 bands for $R$. sp. Heterogeneity and homogeneity were among and within species of Raillietina.

The RAPD profile obtained with primer 
P8 showed that the primer amplified three to five DNA fragments ranged from 600 to $1,200 \mathrm{bp}$. One dominant band of $800 \mathrm{bp}$ was among the 3 species. It may be considered as a generic molecular marker (Fig. 6A).

P9 primer generated one to seven DNA fragments ranged from $500 \mathrm{bp}$ to $1,200 \mathrm{bp}$. Two DNA segments of 1,000 and 1,050 bp were common among all species except in one individual. Also, R. tetragona samples have four monomorphic bands. The DNA fragment of $500,600,1,000 \& 1,050$ bp present in $R$. tetragnona and $R$. echinobothrida isolates, but absent in $R$. sp. (Fig. 6A).

The primer P10 generated showed eight to twelve DNA bands, some of them were distinct and others were faint. The DNA profile produced various bands ranged from 300 to 1,100 bp. Eight monomorphic DNA bands of $300,450,500,600,650,800,900$ and $1,000 \mathrm{bp}$ were dominant among the three species and considered as a generic molecular marker (Fig. 6B). P12 primer generated 3 to 8 DNA fragments ranged from $400 \mathrm{bp}$ to $1,500 \mathrm{bp}$. DNA fragment of $1,100 \mathrm{bp}$ was in all species samples but faint in $R$. sp. Two fragments of 800 and 1,500 bp were present in all samples except the $R$. echinobothrida sample 2, but DNA fragment of 600 bp was absent only in $R$. tetragona sample 1 . Two dominant fragments of 500bp and $1,050 \mathrm{bp}$ were prominent in $R$. tetragona samples (Fig. 6C).

Arbitrary primer P13 amplified two to six DNA fragments ranged from 400 to 1,100 bp, some of them were distinct and others Table 3: No. of shared bands within 3 species of Raillietina with similarity coefficient. (R.sp: Raillietina sp. sample, R.e1\&R.e2: R. echinobothrida samples, R.t1\&R.t2: R. tetragona samples)

\begin{tabular}{|c|c|c|c|}
\hline Species & SB & SC\% & GD\% \\
\hline R. sp \& R.e1 & 16 & $70 \%$ & $30 \%$ \\
\hline R. sp \& R.e2 & 13 & $50 \%$ & $50 \%$ \\
\hline R. sp \& R.t1 & 15 & $60 \%$ & $40 \%$ \\
\hline R. sp \& R.t2 & 19 & $70 \%$ & $30 \%$ \\
\hline R.e1 \& R.e2 & 20 & $67 \%$ & $33 \%$ \\
\hline R.e1 \& R.t1 & 20 & $67 \%$ & $33 \%$ \\
\hline R.e1 \& R.t2 & 21 & $67 \%$ & $33 \%$ \\
\hline R.e2 \& R.t1 & 21 & $65 \%$ & $35 \%$ \\
\hline R.e2 \& R.t2 & 21 & $62 \%$ & $38 \%$ \\
\hline R.t1 \& R.t2 & 24 & $72 \%$ & $28 \%$ \\
\hline
\end{tabular}

were faint. This primer amplified polymerphic bands. Individuals of $R$. echinobothrida showed five monomorphic bands of 400, 500, 600, 1,000 and 1,100 bp. Two DNA bands of 400 and 700 bp were dominant in all samples except one (Fig. 6D).

Primer P33 amplified 1 to 6 polymorphic DNA fragments in range of 200 to $1,200 \mathrm{bp}$ for them. Individuals of $R$. echinobothrida and $R$. tetragona showed five monomorphic bands of 200, 300, 500, $800 \& 1,200$ bp. $R$. sp. showed one band of $600 \mathrm{bp}$ (Fig. 6C).

Primer P12 generated the maximum bands size (1,500bp) among all primers. There were some bands with high intensity and others with faint appearance. Primers amplified different classes, monomorphic, polymorphic and high frequency polymorphic. Primers (P8, P10 \& P12) yielded both monomorphic and polymorphic bands, but P9, P13 \& P33 generated polymorphic fragments, yielding band patterns with a high degree of divergence among Raillietina species that allowed easy distinction between them. The six primers yielded distinguishable band patterns among them and individuals within same species. High similarity coefficient (Tab. 3) was $70 \%$ between $R$. sp. \& R. echinobothrida (R. sp. \& R.e1) and between $R$. sp. and R. tetragona (R. sp. \& R.t2). In one hand, the lowest SC (62\%) was found between $R$. echinobothrida and $R$. tetragona (R.e2 \& R.t2). The SCs within individuals of the same species were $67 \%$ for $R$. echinobothrida (R.e1 \& R.e2) and $72 \%$ for $R$.

\section{tetragona (R.t1 \& R.t2).}


SSCP-PCR: R. echinobothrida (1 sample), $R$. tetragona (2 samples), and $R$. sp. (1 sample) were subjected to PCR analysis to amplify mitochondrial $12 \mathrm{~S}$ rRNA and Cytochrome $C$ oxidase $(\mathrm{CO} 1)$ genes. DNA samples from them were randomly selected to eliminate individual variation. The amplification of $12 \mathrm{~S}$ rRNA gene (Fig. 7A) of all isolates produced a fragment of approximately $250 \mathrm{bp}$. While amplification products of COl (Fig. 7B) were $450 \sim 500 \mathrm{bp}$ fragments in all isolates.

Each PCR product was denatured and loaded in a different lane of a polyacrylamide gel. Although there was no variation in size among the PCR products on agarose gel, three distinct profiles were distinguished among the 3 species in the COl gene in SSCP analysis. $R$. tetragona homozygous individuals have nearly the same pattern except in one band (Fig. 8A, lane $1 \& 2$ ), but individuals of $R$. sp. and $R$. echinobothrida presented six and seven bands respectively with different electro-phoretic mobility (Fig. $8 \mathrm{~A}$, lane $3 \& 4$ ). In $12 \mathrm{~S}$ rRNA gene, SSCP analysis gave nearly the same profiles among Raillietina species but with different electrophoretic mobility for each (Fig. 8B).

\section{Discussion}

The whole prevalence of the intestinal helminthes of domesticated pigeon $(C . l$. domestica) was $24.79 \%$. Highest infection rate was in the fall season $(33.11 \%)$ followed by summer $(13.3 \%)$, but without infection in winter and spring seasons. This percentage was higher than Eljadar et al. (2012) who found prevalence values of 5\%, but, relatively low with other studies worldwide. In Iran, prevalence was $84.78 \%$ (Radfar et al, 2012), in India was $91 \%$ (Par-sani et al, 2014), and ranged from $46 \%$ to $100 \%$ in Brazil (Tietz Marques et al, 2007), Nigeria (Adang et al, 2008; Opara et al, 2012; Buba et al., 2018), Iraq (Al-Barwari and Saeed, 2012), Egypt (El-Dakhly et al, 2018) and Libya (Alkharigy et al, 2018).
In the present study, prevalence was $19.5 \%$, or lower than Chaechi-Nosrati et al. (2018) and Laku et al. (2018) reported $36.66 \%$ \& $28 \%$ respectively. Also, prevalence of single nematode infection was $3.65 \%$, which different from Borji et al. (2012) who reported $21.6 \%$, but nearly similar to cestode $15.3 \%$. Nematode infect-ions $\%$ differed from Chaechi-Nosrati et al. (2018) who reported $40.5 \%$ but similar to Laku et al. (2018) who reported $4 \%$.

In the present study, higher prevalence of nematode infections was in summer $(2.66 \%)$ and fall $(4.54 \%)$ seasons. This agreed with Moudgil et al. (2019) who reported that the higher prevalence was in windy seasons that accompanied by precipitation and also in summer season. This could be attributed to the favorable environmental conditions (high humidity and suitable temperature) for development and prolonged infective parasitic stages survival (Singh et al, 2009). Seasonal climatic conditions interfered with feed and water resulted in stress and decreased immunity, leading to more vulnerability to parasitosis (Dhoot et al, 2002).

The helminthes prevalence of Egyptian domestic pigeon was relatively low as compared with studies worldwide. This variations in results and percentage in the present study compared to other studies (even higher or lower) and the presence of other reported species of cestodes in other countries may be due to abundance and presence of intermediate hosts (as ants, cockroaches, beetles, earthworms, \& some molluscs), host species and its feeding habits, climate factors and geographical factors in Egypt. No trematodes were recorded due to their preferable feeding habits lacking intermediate hosts.

In the present study, for specific identification, the recovered cestode parasites were compared with those from different regions worldwide and they were $R$. tetragona and Raillietina sp. with a rounded rostellum and oval suckers, but $R$. echin- 
obothrida with small round rostellum and rounded suckers. Also, rostellar hooks of $R$. tetragona were arranged in a single row while those of other 2 species were in 2 rows. Yamaguti (1958); Schmidt (1986) Butboonchoo et al. (2016) reported that some morphological criteria confirmed cestodes identifications. The present $R$. tetragona was similar to that of Sawada (1965), Albadalejo (1995) and Butboonchoo et al. (2016).

Sawada (1965), Albadalejo (1995), Baker (2008) and Butboonchoo et al. (2016) recorded 6 to 12 eggs per egg capsule in $R$. tetragona, that differs from the present study, that recorded 5 to 11 eggs in egg capsule. In the present study, shape and size of $R$. echinobothrida were closely related to that described by (Dehlawi, 2007; Lalchhandama, 2009; Al-Marsomy and Al-Hamadaani, 2016; Ibrahim et al, 2018). However, it differed from the des-cription of Al-Marsomy and Al-Hama-daani (2016) in scolex width and roste-llum diameter, they recorded 0.04 $\& 0.027 \mathrm{~mm}$ respectively, in the present study, were $0.27 \& 0.1 \mathrm{~mm}$ respectively. The present description of $R$. echinobothrida agreed with the description of Lalchhandama (2009) and Butboonchoo et al. (2016). They described an oval to rounded armed suckers, an armed rostellum with two rows of hammer-shaped hooks and unilateral posterior genital. It differed with Lalchhandama (2009) who reported $R$. echinobothri$d a$ with a single egg in the egg capsule.

Comparing studies on different species of Raillietina described, Raillietina sp. of the present study cannot be exactly identified. It differed from $R$. tetragona in the present study in having a double circles of rostellar hooks, a relatively longer neck $(1.3 \mathrm{~mm}$ in Raillietina sp. compared with $0.35 \mathrm{~mm}$ in $R$. tetragona), larger number of testes (30-36 Raillietina sp. compared with $25-28$ in $R$. tetragona), number of eggs per egg capsule (4-8 in Raillietina sp. compared with 5-11 in $R$. tetragona) and different shape of scolex (Raillietina sp. has a nearly squared scolex compared with an oval one of $R$. tetragona). Raillietina sp. also differed with $R$. echinobothrida in scolex shape (Raillietina sp. with a nearly squared scolex but rounded one of $R$. tetragona), the length of the neck $(1.3 \mathrm{~mm}$ in Raillietina sp. compared with $0.45 \mathrm{~mm}$ in $R$. tetragona) and number of testes (30-36 in Raillietina sp. compared with 23-26 in R. tetragona). Raillietina sp. in the present study was related to $R$. saudiae that described by Al Quraishy et al. (2019). They described a Raillietina with 2 rows of hammer-shaped rostellar hooks with range number of 230 to 250 and testes number of 27 to 37 , unilateral genital pore and 5 to 6 eggs in egg pouch. They differed in the absence of the neck.

In the present study Raillietina sp. may be closely related to $R$. zahratis described by Magzoub et al. (1980), as a worm with two rows of hammer-shaped rostellar hooks; unilateral genital pore opening and 3 to 9 eggs in egg pouch. But, it differed in the number of testes (12 to 15 to R. zahratis and 30 to 36 in Raillietina sp.).

The present Cotugnia digonopora was closely similar to C. magdoubii of Magzoub et al. (1980) in worm size, number of testes and in genital pores arrangement. But, it differed in scolex width, rostellum diameter and suckers and the cirrus pouch length (Magzoub et al, 1980). In the present study, C. digonopora was similar to that of Meggitt (1926) and Magzoub et al. (1980) in having two sets of reproductive organs, cup-shaped muscular suckers, and rostellum with double rows of very small hooks. But, it differs in the number of testes, both reported 100 testes while in the present study there were about 37-42 testes in each set of organs.

In the present study, Choanotaenia infundibulum agreed with Lincicome (1939) and Sawada (1970). Baker (2008) reported that C. infundibulum was $23 \mathrm{~cm}$ long; scolex bears an armed rostellum with 16 to 22 hooks arranged in one circle measured 0.02 to 0.03 $\mathrm{mm}$ in length. But, Arulmozhi et al. (2018) found that $C$. infundibulum measured 15 to 
$22 \times 2.5$ to $3 \mathrm{~mm}$, a small scolex with suckers and rostellum armed with 16-20 slender hooks. Egg had an ovoid shape, measured $0.03 \times 0.045 \mathrm{~mm}$ similar to the study $C$. infundibulum described. Intestinal helminthes are frequently identified on the basis of morphological characters, their transmission methods or their pathological effects on their hosts (Lichtenfels et al, 1997). These criteria are often insufficient for specific identification. Using molecular techniques for species identification increased knowledge and data for recognition, identification, and phylogenetic relationships of Raillietina species.

RAPD-PCR was identified by Gasser (2006) as DNA fingerprinting method easily produced complex and informative genomic fingerprints. In Raillietina species (Raillietina sp., $R$. echinobothrida, and R. tetragona) under investigation, RAPD-PCR data showed that Raillietina sp. was closely related to $R$. echinobothrida and $R$. tetragona with $70 \%$ similar coefficient. $R$. echinobothrida and $R$. tetragona were $67 \%$ related. SSCP technique (12S rRNA and Cytochrome $C$ oxidase (COI) genes) proved that the three species were closely related to each other by having nearly identical bands pattern. This agreed with (Littlewood et al., 2008; Butboonchoo and Wongsawad, 2017) who stated that $R$. echinobothrida and $R$. tetragona were more related to each other than Raillietina species as their definitive host is domestic chickens but, other species use other birds as final hosts. Ghobashy and Taeleb (2015) used RAPD-PCR to identify Raillietina spp. of infected domestic and wild pigeons from Sharkia Governorate found sequence similarities confirmed that Raillietina spp. was related to other species of order Cyclophyllidea. Sequence of worm samples showed homology to $R$. beveridgei. Wolf et al. (2005) and Jyrwa et al. (2014) estimated the validity of ITS2 gene region in distinguishing related Raillietina species and recommended that more studies was a must to exploit the ITS2 and other markers for robust molecular characterization of these avian parasites. Ibrahim et al. (2018) used molecular analysis of gene (ITS2) to differentiate between two Raillietina species ( $R$. beveridgei \& $R$. echinobothridia) found that ITS2 gene was composed a phylogenetic tree using related sequences available on the GenBank.

\section{Conclusion}

RAPD-PCR \& SSCP-PCR techniques proved to be the most reliable techniques in identification of species and in detecting intraspecific genetic variations between closely related and similar parasites of same species.

\section{References}

Adang, LK, Abdu, PA, Ajanusi, JO, et al, 2018: Effects of Ascaridia galli infection on body weight and blood parameters of experimentally infected Columba livia domestica in Zaria, Nigeria. UDO Agríc. 4.

Al Quraishy, S, Abdel-Gaber, R, Alajmi, R, et al, 2019: Morphological and molecular appraisal of cyclophyllidean cestoda parasite Raillietina saudiae sp. infecting the domestic pigeon $\mathrm{Co}$ lumba livia domestica and its role as a bio-indicator for environmental quality. Parasitol. Inter. 5:72-9.

Albadalejo, A, Acosta, I, Alonso, FD, 1995: Hallazgo del cestodo Raíllíetina tetragona (Molin, 1858) como parásito de la paloma doméstica Columba livia. Anal. Vet. Murcia. 11:51-6.

Al-Barwari, S, Saeed, I, 2012: The parasitic communities of the rock pigeon Columba livia from Iraq: component and importance. Türkiye Paraz. Dergisi, 36, 4: 232.

Alkharigy, FA, El Naas, AS, Maghrbi, AA, 2018: Survey of parasites in domestic pigeons (Columba livia) in Tripoli, Libya. Open vet. J. 8, 4: 360-6.

Al-Marsomy, WA, Al-Hamadaani, HS, 2016: Association of Cestoda Raillietina echinobothrida in Rock Pigeon Columba livia from Baghdad city of Iraq. Baghdad Sci. J. 13, 3:463-8.

Arulmozhi, A, Anbarasi, P, Madheswaran, R, et al, 2018: Choanotaenia infundibulum, rare outbreak in Japanese quails Coturnix coturni japonica. Indian Vet. J. 95:48-50.

Baker, DG, 2008: Flynn's Parasites of Laboratory Animals. John Wiley \& Sons.

Borji, H, Moghaddas, E, Razmi, GR, et al, 2012: A survey of ecto- and endo-parasites of domestic pigeons (Columba livia) in Mashhad, 
Iran. Iranian J. Vet. Sci. Tech. 4, 2:37-42.

Buba, ZM, Ambas, PF, Elihu, A, et al, 2018: Prevalence of gastrointestinal parasite of domestic pigeon (Columba Livia) in Mubi North of Adamawa State, Nigeria. Int. J. Innov. R. 5:3159.

Butboonchoo, P, Wongsawad, C, 2017: Occurrence and HAT-RAPD analysis of gastrointestinal helminths in domestic chickens ( $\mathrm{Gal}$ lus gallus domesticus) in Phayao Province, northern Thailand. Saudi J. Biol. Sci. 24, 1:30-5.

Butboonchoo, P, Wongsawad, C, Rojanapaibul, A, et al, 2016: Morphology and molecular phylogeny of Raillietina spp. (Cestoda: Cyclophyllidea: Davaineidae) from domestic chickens in Thailand. Korean J. Parasitol. 54, 6:77-9.

Branckaert, RD, Gaviria, L, Jallade, J, et al, 2000: Transfer of technology in poultry production for developing countries. World's Poultry Congress, 20-24.

Caira, JN, Jensen, K, Waeschenbach, A, et al, 2014: Orders out of chaos-molecular phylogenetics reveals the complexity of shark and stingray tapeworm relationships. Int. J. Parasitol. 44, 1:55-73.

Catelli, CT, Poglayen, G, Gadale, AT, 1999: Preliminary study of the helminths of the chicken digestive tract in Somalia. Pathol. Fectieuse, 52, 2:107-12.

Chaechi-Nosrati, MR, Eslami, A, Rahbari, S, et al, 2018: The survey of parasitic infections of wild pigeons (Columba livia) in Lahijan City, Guilan, Iran. Compar. Clin. Pathol. 27, 5:14058.

Dehlawi, MS, 2007: The occurrence of nematodes in the intestine of local (Baladi) chicken (Gallus gallus domesticus) in Jeddah Province, Saudi Arabia. Sci. J. King Faisal U. 8, 2: 61-71.

Dessie, T, Ogle, B, 2001: Village poultry production systems in the central highlands of Ethiopia. Trop. Anim. Hlth. Prod. 33, 6:521-37.

Dhoot, VM, Upadhye, SV, Kolte, SW, 2002: Prevalence of parasitism in wild animals and birds of Maharajbag Zoo, Nagpur. Indian Vet. J. 79, 3:225-7.

Dinkel, A, Njoroge, EM, Zimmermann, A, et al, 2004: A PCR system for detection of species and genotypes of the Echinococcus granulosus complex, with reference to the epidemiological situation in eastern Africa. Int. J. Parasitol. 34, 5:645-53.

Dranzoa, C, Ocaido, M, Katete, P, 1999: The ecto-, gastro-intestinal and haemo-parasites of live pigeons (Columba livia) in Kampala, Uganda. Avian Pathol. 28, 2:119-24.

El-Dakhly, KM, El-Seify, MA, Mohammed, ES, et al, 2018: Prevalence and distribution pattern of intestinal helminths in chicken and pigeons in Aswan, Upper Egypt. Trop. Anim. Prod. 3:1-6.

Eljadar, M, Saad, W, Elfadel, G, 2012: A study on the prevalence of endoparasites of domestic pigeons (Columba livia domestica) inhibiting in the green mountain region of Libya. J. Am. Sci. 8:12.

Eom, KS, Jeon, HK, Kong, Y, et al, 2002: Identification of Taenia asiatica in China: molecular, morphological, and epidemiologi-cal analysis of a Luzhai isolate. J. Parasitol. 88, 4: 758-64.

Eshetu, Y, Mulualem, E, Ibrahim, H, et al, 2001: Study of gastro-intestinal helminths of scavenging chickens in four rural districts of Amhara region, Ethiopia. Sci. Tech. Inter. Epizooties 20, 3:791-3.

Gasser, RB, 2006: Molecular tools advances, opportunities and prospects. Vet. Parasitol. 136: 69-89.

Ghobashy, MA, Taeleb, AA, 2015: Molecular characterization of Raillietina (r.) spp. Ortlepp, 1938 (Cestode: Cyclophyllidea: Davaineidae) infecting domestic and wild bird (Columba livia \& C. l. domestica). World J. Zool. 10, 2: 136-41.

Ibrahim, NA, Hassan, EA, Moawad, T, et al, 2018: Morphological and molecular identification of some intestinal helminthes infesting the domestic pigeon (Columba livia domestica) at Ismailia, Egypt. Inter. J. Environ. Sci. 16, 2:6170.

Ikeme, MM, 1971: Weight changes in chickens placed on different levels of nutrition and varying degrees of repeated dosage with Ascaridia galli eggs. Parasitol. 63, 2:251-60.

Jadhav, BV, Gore, GD, 2004: A new species of genus Cotugnia (Diamare, 1813) from pigeon, Columba livia at Loha. India. Nat. J. Life Sci. 1, 1:181-2.

Jyrwa, DB, Dutta, AK, Das, B, et al, 2014: Molecular characterization of the Indian poultry nodular tapeworm, Raillietina echinobothrida (Cestoda: Cyclophyllidea: Davaineidae) based on rDNA internal transcribed spacer 2 region. J. Parasitol. Dis. 38, 1:22-6.

Laku, CB, Onwuteaka, JN, Amuzie, CC, 2018: Ecto-parasites and intestinal helminth community of domesticated pigeons (Columba liv- 
ia) of Trans-Amadi Abattoir, Port arcourt, Nigeria. J. Gastroenterol. Forecast. 1:2-7.

Lalchhandama, K, 2009: On the structure of Raillietina echinobothrida, the tapeworm of domestic fowl Sci. Vis. 4:174-82.

Lavikainen, A, Haukisalmi, V, Lehtinen, MJ, et al, 2008: A phylogeny of members of the family Taeniidae based on the mitochondrial cox1 and nad1 gene data. Parasitol. 135, 12:1457-67.

Lichtenfels, JR, Hoberg, EP, Zarlenga, DS, 1997: Systematics of gastrointestinal nematodes of domestic ruminants: advances between 1992 and 1995 and proposals for future research. Vet. Parasitol. 72, 3/4:225-45.

Lincicome, DR, 1939: A new tapeworm, Choanotaenia iola, from the robin. J. Parasitol. 25, 3:203-6.

Littlewood, DT, Waeschenbach, A, Nikolov, P $\mathbf{N}$, 2008: In search of mitochondrial markers for resolving the phylogeny of cyclophyllidean tapeworms (Platyhelminthes, Cestoda) a test study with Davaineidae. Acta Parasitol. 53, 2:133-44.

Magzoub, M, Kasim, AA, Shawa, Y, 1980: Three new species (Cestoda: Davaineidae) from the rock pigeon Columba livia domestica with comments on the infection. J. Coll. Sci. Riyadh Uni. 11:119-27.

Moudgil, AD, Singla, LD, Singh, MP, 2019: Seasonal variation in gastrointestinal parasiteism of zoo-housed birds of Punjab, India. Bio. Rhythm Res. 1-12.

Mungube, EO, Bauni, SM, Tenhagen, BA, et al, 2008: Prevalence of parasites of the local scavenging chickens in a selected semi-arid zone of Eastern Kenya. Trop. Anim. Prod. 40, 2:1019.

Nei, M, Li, WH, 1979: Mathematical model for studying genetic variation in terms of restriction endonucleases. Nat. Acad. Sci. 76, 10:5269-73.

Opara, MN, Ogbuewu, IP, Iwuji, CT, et al, 2012: Blood characteristics, microbial and gastrointestinal parasites of street pigeons (Columbia livia) in Owerri, Imo State, Nigeria. Sci. J. Snim. Sci. 1, 1:14-21.
Parsani, HR, Momin, RR, Lateef, A, et al, 2014: Gastro-intestinal helminthes of pigeons (Columba livia) in Gujarat, India. Egypt. J. Biol. 16, 1:63-71.

Radfar, MH, Khedri, J, Adinehbeigi, K, et al, 2012: Prevalence of parasites and associa-ted risk factors in domestic pigeons (Columba livia domestica) and free-range backyard Sari, B, Karatepe, B, Karatepe, M, et al, 2008: Parasites of domestic (Columba livia domestica) and wild (Columba livia livia) pigeons in nigde, Turkey. Bull. Vet. Inst. 52: 551-4.

Satish, S, Priti, M, 2013: Gastro intestinal helminths parasites of local chickens samples from tribal areas of Madhya Pradesh. Int. J. Life Sci. 1, 4:284-7.

Sawada, I, 1970: On the fowl cestode, Choanotaenia infundibulum, from Brazil. Bull. Nara. Uni. Educ. 19, 2:81-2.

Sawada, L, 1965: On the genus Raillietina fuhrmann 1920. J. Nara. Gakugei Uni. 12: 19-36.

Schmidt, GD, 1986: CRC Handbook of Tapeworm Identification. CRC Press, Inc. Boca Raton, Florida.

Singh, P, Singla, LD, Gupta, MP, et al, 2009: Epidemiology \& chemotherapy of (SSCP) based mutation scanning approaches chickens of Sistan region, east Iran. J. Parasitol. Dis. 36, 2:220-5.

Thrusfield, M, 1995: Diagnostic testing. Vet. Epidemiol. 2: 266-85.

Williams, JG, Kubelik, AR, Livak, KJ, et al, 1990: DNA polymorphisms amplified by arbitrary primers are useful as genetic markers. Nucl. Acids Res. 18, 22:6531-5.

Wolf, M, Achtziger, M, Schultz, J, et al, 2005: Homology modeling revealed more than 20,000 rRNA internal transcribed spacer 2 (ITS2) secondary structures. RNA 11, 11: 1616-23.

Yamaguti, S, 1958: Systemia Helmenthum. Interscience Publishers, New York., USA

Zhu, XQ, Gasser, RB, 1998: Single-strand conformation polymorphism (SSCP) based mutation scanning approaches to fingerprint sequence variation in ribosomal DNA of ascaridoid nematodes. Electrophoresis, 19, 8/9: 1366-73.

\section{Explanations of figures}

Fig.1: Raillietina tetragona recovered from Columba livia domestica stained with acetocarmine. A. Scolex with higher magnification of rostellar hooks. (S: Sucker, R: Rostellum RH: Rostellar hooks). B. Mature proglottid. (GP: Genital pore, O: Ovary, T: Testes). C. Gravid proglottid. (E: Egg, EC: Egg capsule)

Fig. 2: Raillietina echinobothrida recovered from C. l. domestica stained with acetocarmine. A. Scolex with higher magnification of rostellar hooks. (S: Sucker, R: Rostellum, RH: Rostellar hooks). B. Mature proglottid. C. Gravid proglottid.

Fig. 3: Raillietina sp. recovered from C. l. domestica stained with acetocarmine. A. Scolex with higher magnification of rostellar hooks. B. Mature proglottid. C. Gravid proglottid.

Fig. 4: Cotugnia digonopora recovered from C. l. domestica stained with acetocarmine. A. Scolex with higher magnification of rostellar hooks. B. Mature proglottid. C. Gravid proglottid. (E: Egg) 
Fig. 5: Choanotaenia infundibulum recovered from C. l. domestica stained with acetocarmine, A. Scolex with higher magnification of rotellar hooks. B. Mature proglottid. C. Gravid proglottid.

Fig. 6: Agarose gel electrophoresis of RAPD-PCR of 3 species of Raillietina. A. Using primers P8 \& P9. B. Using primer P 10. C. Using primers P12 \& P33. D. Using primer P13. (R.sp: Raillietina sp. sample, R.e1\&R.e2: R. echinobothrida samples, R.t1\&R.t2: R. tetragona samples, M: 100 bp DNA ladder)

Fig. 7: Agarose gel electrophoresis of PCR detection of A. Cytochrome C oxidase subunit (CO1) gene. B. Mitochondrial 12sRNA gene in 3 species of Raillietina.

Fig. 8: Agarose gel electrophoresis stained with silver nitrate of SSCP-PCR assay of A. Cytochrome C oxidase subunit (CO1) gene. B. Mitochondrial 12S rRNA gene amplified in 3 species of Raillietina.

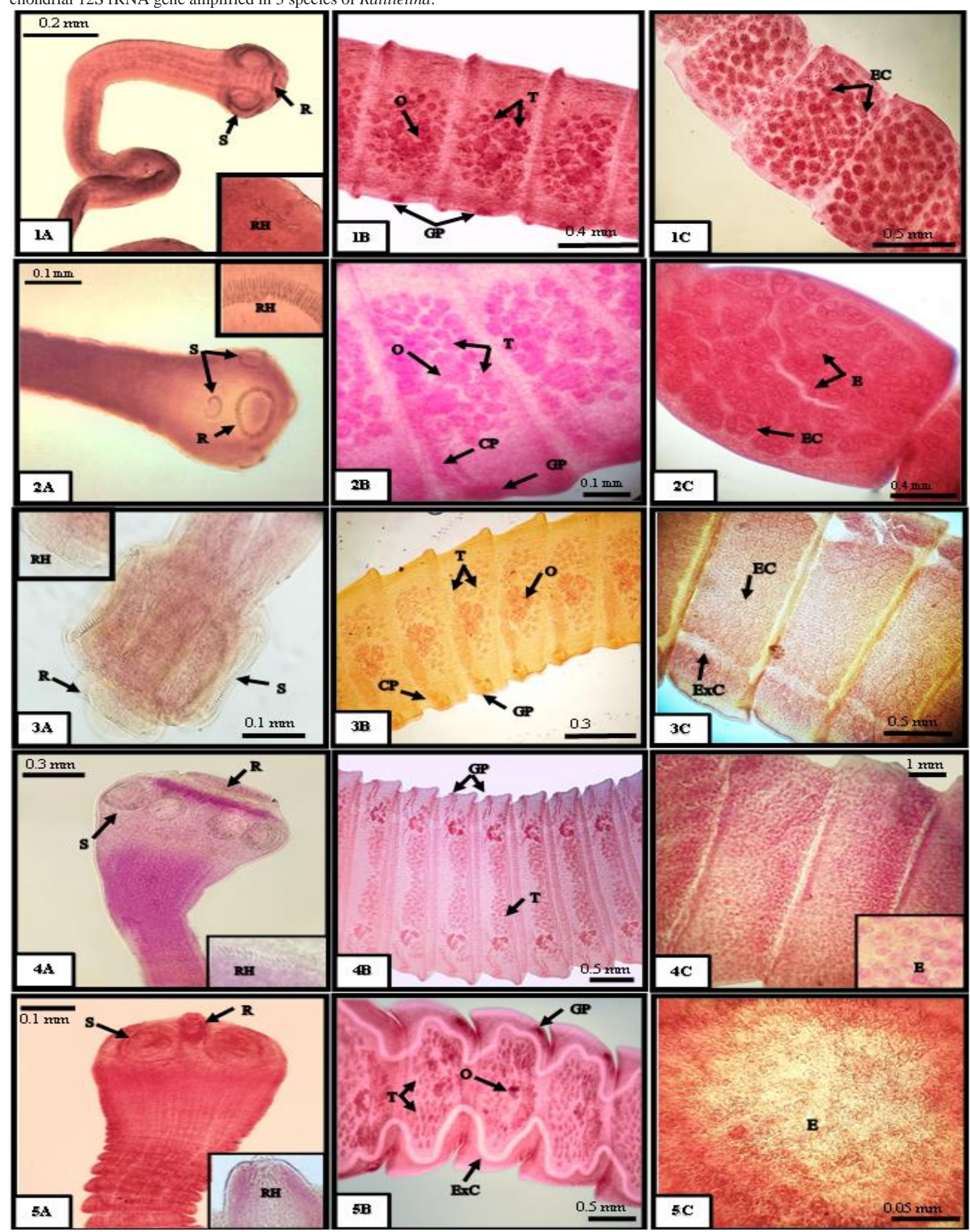




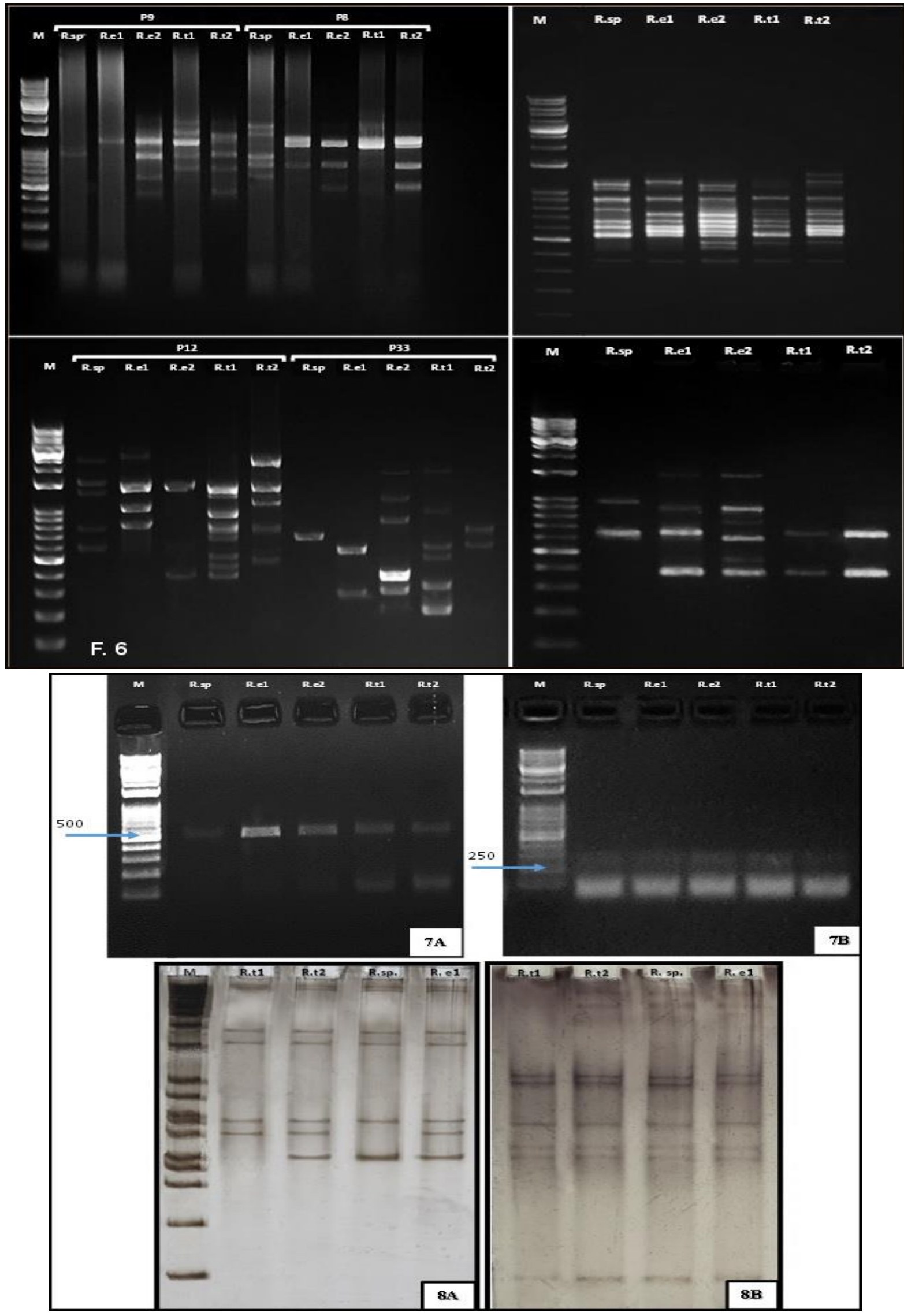

